\title{
Cloning and sequence analysis of a partial CDS of leptospiral ligA gene in PET-32a - Escherichia coli DH5a system
}

\author{
Manju Soman ${ }^{1}$, Mangattuparambil Mini ${ }^{1}$, Siju Joseph ${ }^{2}$, Jobin Thomas ${ }^{3}$, Nirmal Chacko ${ }^{4}$, T. G. Sumithra ${ }^{5}$, R. Ambily ${ }^{1}$,
} Binu K. Mani ${ }^{1}$ and Rinsha Balan ${ }^{1}$

\begin{abstract}
1. Department of Veterinary Microbiology, College of Veterinary and Animal Sciences, Mannuthy, Thrissur - 680651 , Kerala, India; 2. Department of Veterinary Microbiology, College of Veterinary and Animal Sciences, Pookode, Wayanad, Kerala, India; 3. Unidad de Sanidad y Biotecnologia (SaBio), Instituto de Investigación en Recursos Cinegéticos (IREC), Universidad de Castilla-La Mancha (UCLM), Ronda de Toledo s/n 13071, Ciudad Real, Spain; 4. Department of Animal Husbandry, Veterinary Dispensary Balanthode, Panathady, Kasargod, Kerala, India; 5. ICAR-Central Marine Fisheries Research Institute, Post Box No. 1603, Ernakulam North, Cochin - 682 018, Kerala, India.

Corresponding author: Manju Soman, e-mail: manjuso1993@gmail.com

Co-authors: MM: mini@kvasu.ac.in, SJ: siju@kvasu.ac.in, JT: jobs2k6@gmail.com, NC: nirmalkollaka@gmail.com, TGS: sumithravet@gmail.com, RA: ambilysd@gmail.com, BKM: binu@kvasu.ac.in, RB: rinshabalanvet@gmail.com Received: 31-12-2017, Accepted: 31-03-2018, Published online: 30-04-2018
\end{abstract}

doi: 10.14202/vetworld.2018.557-561 How to cite this article: Soman M, Mini M, Joseph S, Thomas J, Chacko N, Sumithra TG, Ambily R, Mani BK, Balan R (2018) Cloning and sequence analysis of a partial CDS of leptospiral ligA gene in pET-32a - Escherichia coli DH5a system, Veterinary World, 11(4): 557-561.

\begin{abstract}
Aim: This study aims at cloning, sequencing, and phylogenetic analysis of a partial CDS of ligA gene in pET-32a - Escherichia coli DH5 $\alpha$ system, with the objective of identifying the conserved nature of the ligA gene in the genus Leptospira.

Materials and Methods: A partial CDS (nucleotide 1873 to nucleotide 3363) of the ligA gene was amplified from genomic DNA of Leptospira interrogans serovar Canicola by polymerase chain reaction (PCR). The PCR-amplified DNA was cloned into pET-32a vector and transformed into competent $E$. coli DH5 $\alpha$ bacterial cells. The partial ligA gene insert was sequenced and the nucleotide sequences obtained were aligned with the published lig $A$ gene sequences of other Leptospira serovars, using nucleotide BLAST, NCBI. Phylogenetic analysis of the gene sequence was done by maximum likelihood method using Mega 6.06 software.

Results: The PCR could amplify the 1491 nucleotide sequence spanning from nucleotide 1873 to nucleotide 3363 of the $\operatorname{lig} A$ gene and the partial ligA gene could be successfully cloned in E. coli DH5 $\alpha$ cells. The nucleotide sequence when analyzed for homology with the reported gene sequences of other Leptospira serovars was found to have $100 \%$ homology to the $1910 \mathrm{bp}$ to $3320 \mathrm{bp}$ sequence of ligA gene of L. interrogans strain Kito serogroup Canicola. The predicted protein consisted of 470 aminoacids. Phylogenetic analysis revealed that the ligA gene was conserved in L. interrogans species.

Conclusion: The partial ligA gene could be successfully cloned and sequenced from E. coli DH5 $\alpha$ cells. The sequence showed $100 \%$ homology to the published $\operatorname{lig} A$ gene sequences. The phylogenetic analysis revealed the conserved nature of the $\operatorname{lig} A$ gene. Further studies on the expression and immunogenicity of the partial LigA protein need to be carried out to determine its competence as a subunit vaccine candidate.
\end{abstract}

Keywords: cloning, Escherichia coli DH5a, Leptospira, ligA, pET-32a, phylogenetic tree.

\section{Introduction}

Epidemics of leptospirosis continue to occur in tropical developing countries, due to poor standards of sanitation and hygiene that leave people and animal at risk to the disease [1]. Leptospirosis is caused by a Spirochaete of the genus, Leptospira, which comprises about 22 genomospecies, further divided into about 300 antigenically different serovars [2,3]. Recently, 12 new species of Leptospira have also been identified [4].

Currently available whole-cell inactivated vaccines provide only serovar-specific, short-term

Copyright: Soman, et al. Open Access. This article is distributed under the terms of the Creative Commons Attribution 4.0 International License (http://creativecommons.org/licenses/ by/4.0/), which permits unrestricted use, distribution, and reproduction in any medium, provided you give appropriate credit to the original author(s) and the source, provide a link to the Creative Commons license, and indicate if changes were made. The Creative Commons Public Domain Dedication waiver (http:// creativecommons.org/publicdomain/zero/1.0/) applies to the data made available in this article, unless otherwise stated. immunity and can afford little cross-protection against the different leptospiral serovars. Genus-specific leptospiral proteins that are conserved throughout the different serovars of Leptospira which are immunogenic and uniquely expressed during acute infection may help in the development of an effective vaccine for leptospirosis as well as aid in studies on its pathogenesis [5]. Recombinant DNA technology aids in the production of purified recombinant genus-specific proteins in bulk quantities and hence helps in the development of subunit vaccines for various infections.

This study aims at cloning of a highly immunodominant region of the ligA gene of Leptospira in the pET32 vector - E. coli DH5 $\alpha$ system followed by sequencing and phylogenetic analysis of the partial $\operatorname{lig} A$ gene.

\section{Materials and Methods}

\section{Ethical approval}

All the procedures have been carried out in accordance with the guidelines laid down by the 
Institutional Ethics Committee and with local laws and regulations

\section{Amplification of partial CDS of ligA gene}

The genomic DNA of Leptospira interrogans serovar Canicola was extracted using QIAamp DNA Mini Kit (Qiagen). The extracted DNA was used as template in polymerase chain reaction (PCR) for amplification of partial CDS of ligA gene. Oligonucleotide primers (LigA $\mathrm{F}$ and $\operatorname{LigA} \mathrm{R}$ ) were designed for a $1491 \mathrm{bp}$ nucleotide fragment, corresponding to nucleotides 1873-3363 of the complete CDS of ligA gene of L. interrogans serogroup Canicola strain Kito (GenBank accession number EU7002671).

\begin{tabular}{llc}
\hline Primers & Sequence & Size, bp \\
\hline LigA $F$ & GCATA C CAT GG CGTC CTC TAA TAC & 30 \\
& GGA TAT & \\
LigA $R$ & ATA CTCGAG CGT AAC TGG AGT ATA & 32 \\
& AGA ACT CT & \\
\hline
\end{tabular}

Bulk PCR $(100 \mu \mathrm{L})$ was performed in $50 \mu \mathrm{L}$ reaction mixture containing $34 \mu \mathrm{L}$ nuclease-free water, $5 \mu \mathrm{l}$ 10 X PCR buffer, $1 \mu \mathrm{l}$ of $10 \mathrm{mM}$ dNTP mix $(200 \mu \mathrm{M})$, $2 \mu \mathrm{l}(20 \mathrm{pmol})$ of each of the forward and reverse primers, $5 \mu \mathrm{L}$ of suitably diluted DNA template, and $1 \mu \mathrm{l}$ of Jumpstart Taq DNA polymerase. The PCR amplification cycle comprised an initial denaturation cycle at $96^{\circ} \mathrm{C}$ for $30 \mathrm{~s}$ followed by 35 cycles of denaturation $\left(96^{\circ} \mathrm{C}\right.$ for $15 \mathrm{~s})$, annealing $\left(55^{\circ} \mathrm{C}\right.$ for $\left.30 \mathrm{~s}\right)$ and extension $\left(68^{\circ} \mathrm{C}\right.$ for $2 \mathrm{~min}$ ), followed by a final extension cycle of $68^{\circ} \mathrm{C}$ for $5 \mathrm{~min}$. The amplified PCR product of $1491 \mathrm{bp}$ was eluted from the agarose gel using GeneJET ${ }^{\mathrm{TM}}$ Gel extraction kit, Thermo Scientific ${ }^{\mathrm{TM}}$, to obtain the purified DNA.

\section{Cloning of partial CDS of ligA gene}

The $1491 \mathrm{bp}$ PCR product obtained from $L$. interrogans serovar Canicola and pET-32a DNA was eluted from the agarose gel using GeneJET Gel extraction kit, Thermo Scientific. Gel-purified ligA DNA and gel-purified pET-32a DNA were digested with restriction enzymes, $\mathrm{NcoI}$ and $\mathrm{XhoI}$ (MBI, Fermentas). The digested products were again gel purified and subjected to ligation reaction using T4 DNA Ligase (MBI Fermentas). The ligation reaction mixture was incubated for $1 \mathrm{~h}$ at $22^{\circ} \mathrm{C}$ and further kept at $4{ }^{\circ} \mathrm{C}$ overnight. Competent cells of $E$. coli $\mathrm{DH} 5 \alpha^{\mathrm{TM}}$ were prepared by calcium chloride method as described by Sambrook and Russell [6] with some modifications. The pET-32a ligA DNA was transformed into competent $E$. coli $\mathrm{DH} 5 \alpha$ cells by heat shock method. Five microliters of ligation mixture was mixed with $200 \mu \mathrm{L}$ of $E$. coli DH5 $\alpha$ competent cells and kept on ice for $1 \mathrm{~h}$. These cells were exposed to heat shock at $42^{\circ} \mathrm{C}$ for exactly $90 \mathrm{~s}$ and immediately kept on ice for $5 \mathrm{~min}$. About $800 \mu \mathrm{L}$ of Luria-Bertani (LB) broth with ampicillin $(100 \mathrm{mg} / \mathrm{mL})$ was added to the transformed cells and incubated at $37^{\circ} \mathrm{C}$ for $45 \mathrm{~min}$. The cells were centrifuged at $6000 \times g$ for $8 \mathrm{~min}$ and the supernatant was discarded retaining $100 \mu \mathrm{L}$ of media to resuspend the cells. The transformed cells were plated on LB agar plates containing ampicillin. Appropriate negative controls with untransformed $E$. coli $\mathrm{DH} 5 \alpha^{\mathrm{TM}}$ cells were also processed simultaneously and the plates were incubated at $37^{\circ} \mathrm{C}$ for $24-36 \mathrm{~h}$. The recombinant clones were screened by colony PCR. The pET-32a lig $A$ plasmid construct was extracted from the transformed E. coli DH5 $\alpha$ using Thermo Scientific Gene JET plasmid Miniprep Kit and subjected to sequencing.

\section{Sequencing and analysis of the partial CDS of ligA gene}

The partial ligA gene insert of pET-32a ligA plasmid was submitted to DNA sequencing facility at SciGenom Services, Kakkanad, Cochin, for nucleotide sequencing using the SP6 and T7 promoter primers by dideoxy chain-termination method [7]. The nucleotide sequences obtained were aligned with the published ligA gene sequences of other Leptospira serovars, using nucleotide BLAST, NCBI.

\section{Phylogenetic analysis}

The phylogenetic analysis involved 8 nucleotide sequences. The sequence alignment was done by ClustalW method in the BioEdit software. Evolutionary analyses were conducted in MEGA 6.06 software [8]. The evolutionary history was inferred using the maximum likelihood method based on the Tamura-Nei model. Initial tree(s) for the heuristic search were obtained automatically by applying Neighbor-Join and BioNJ algorithms to a matrix of pairwise distances estimated using the maximum composite likelihood approach, and then selecting the topology with superior log-likelihood value.

\section{Results}

The genomic DNA isolated from L. interrogans serovar, Canicola, using QIAamp DNA Mini Kit (Qiagen) was of high purity and required concentration $(69.1 \mathrm{ng} / \mu \mathrm{L})$. Primers were designed for the $1491 \mathrm{bp}$ fraction corresponding to nucleotides 18733363 of the complete CDS of ligA gene, with addition of primer tag regions and RE sites for $\mathrm{NcOI}$ and XhoI. The annealing temperature for the $\operatorname{lig} A$ primers was determined as $55^{\circ} \mathrm{C}$. The PCR could amplify the 1491

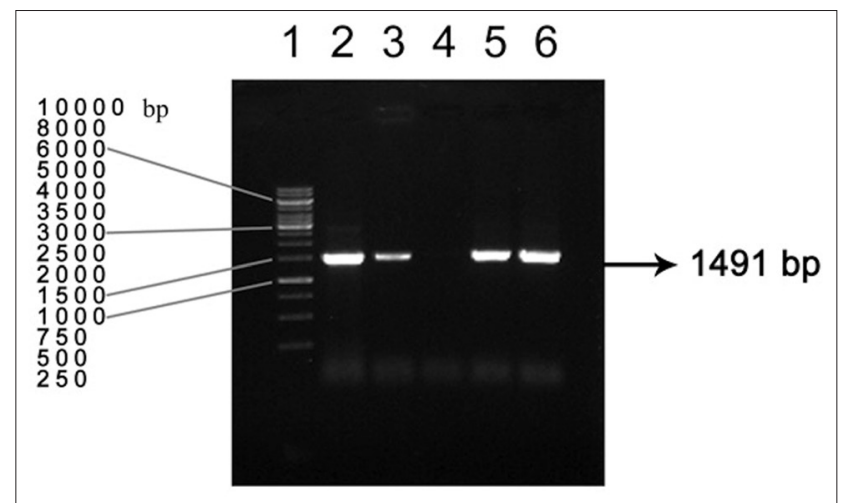

Figure-1: PCR amplification of ligA gene Lane 2,3,5,6positive ampliconsLane 4- negative control Lane 1-DNA marker 
nucleotide sequence spanning from nucleotide 1873 to nucleotide 3363 of the ligA gene (Figure-1).

The pET-32a-transformed E. coli DH5 $\alpha$ plated on LB agar with ampicillin yielded 25-30 colonies following $36 \mathrm{~h}$ of incubation at $37^{\circ} \mathrm{C}$. Control plates inoculated with untransformed $E$. coli $\mathrm{DH} 5 \alpha$ did not yield any colonies. Colony PCR using LigAF and LigAR primers revealed bands at 1491 bp size (Figure-2) on the agarose gel which indicated positive cloning.

\section{Nucleotide sequencing and analysis of partial CDS of ligA gene}

The nucleotide sequence of the partial ligA gene insert of the pET-32a ligA plasmid construct, when analyzed for homology with the reported gene sequences of other Leptospira serovars was found to have 100\% homology to the $1910 \mathrm{bp}$ to $3320 \mathrm{bp}$ sequence of ligA gene of $L$. interrogans strain Kito serogroup Canicola and $99 \%$ homology to $\operatorname{lig} A$ gene (1910-3320 bp) of L. interrogans serovar Kennewicki strain PO-06-047 and ligA gene (1910 bp to $3320 \mathrm{bp}$ ) of L. interrogans serovar Pomona isolate pLPLIGA. The nucleotide sequence has been published in Genbank database

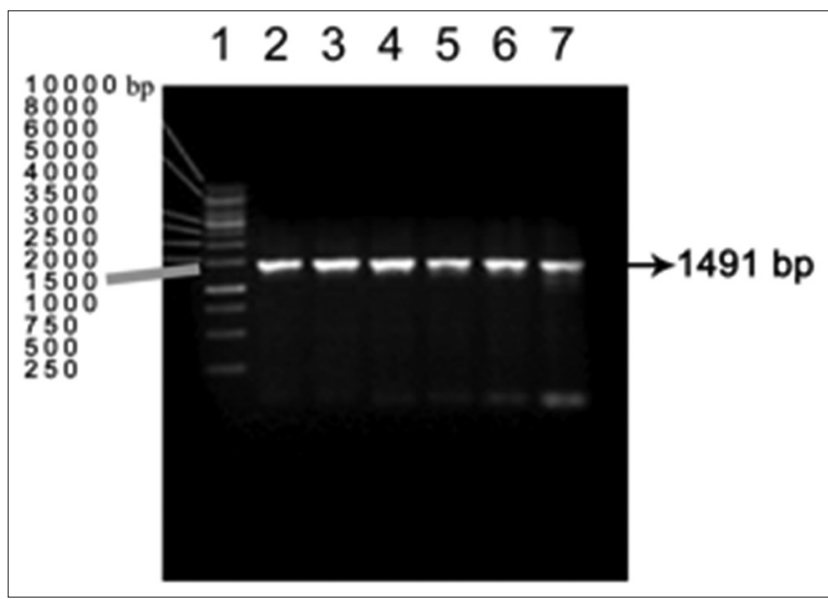

Figure-2: $\mathrm{PCR}$ amplification of E.coli $\mathrm{DH} 5$ a clones Lane 2 to 7 -positive amplicons Lane1- DNA marker of NCBI with the accession number KX964647. The predicted protein, Protein ID APG21200.1, consisted of 470 aminoacids which showed $100 \%$ homology to bacterial immunoglobulin-like domain of $L$. interrogans strain L0996, L. interrogans serovar Medanensis strain L0448, and L. interrogans serovar Canicola strain Fiocruz LV133.

\section{Phylogenetic analysis}

The optimal tree constructed with 8 nucleotide sequences with the highest log likelihood $(-3438.4275)$ is shown in Figure-3.

\section{Discussion}

The Lig (leptospiral Ig-like) protein is a family of surface-exposed lipoproteins found only in pathogenic Leptospira and expressed during acute infection and hence is thought to play a role in the pathogenesis of leptospirosis. The LigA, a $130 \mathrm{kDa}$ protein encoded by the lig $A$ gene, belongs to the Lig family of proteins comprising of LigA and LigB that possess a series of 90 amino acids tandem repeats homologous to the bacterial immunoglobulin-like (Big) domain. The recombination patterns and sequence variations of $\operatorname{lig} A, \operatorname{lig} B$, and $\operatorname{lig} C$ genes, studied in 10 pathogenic strains of five Leptospira species, revealed that ligA might have been created by partial gene duplication of $\operatorname{lig} B$ involving two steps. The amino-terminal domains of LigB and LigA proteins, of strains possessing both genes, were found to be identical having $98.5 \pm 0.8 \%$ mean identity [9]. The LigA proteins are predicted to be lipoproteins as they possess a 17 amino acid $\mathrm{N}$-terminal signal peptide and a lipoprotein signal peptidase cleavage site. The $\operatorname{lig} A$ gene encoding this protein reportedly comprise of 3675 bp with 12 tandem repeats. It has been reported that cloning of full-length $\operatorname{lig} A$ gene in pET-22b plasmid and expression in E. coli produced very low levels of rLigA, which was attributed to the high toxicity of the protein [10]. Several studies have demonstrated the cross-reactive immunoprotective

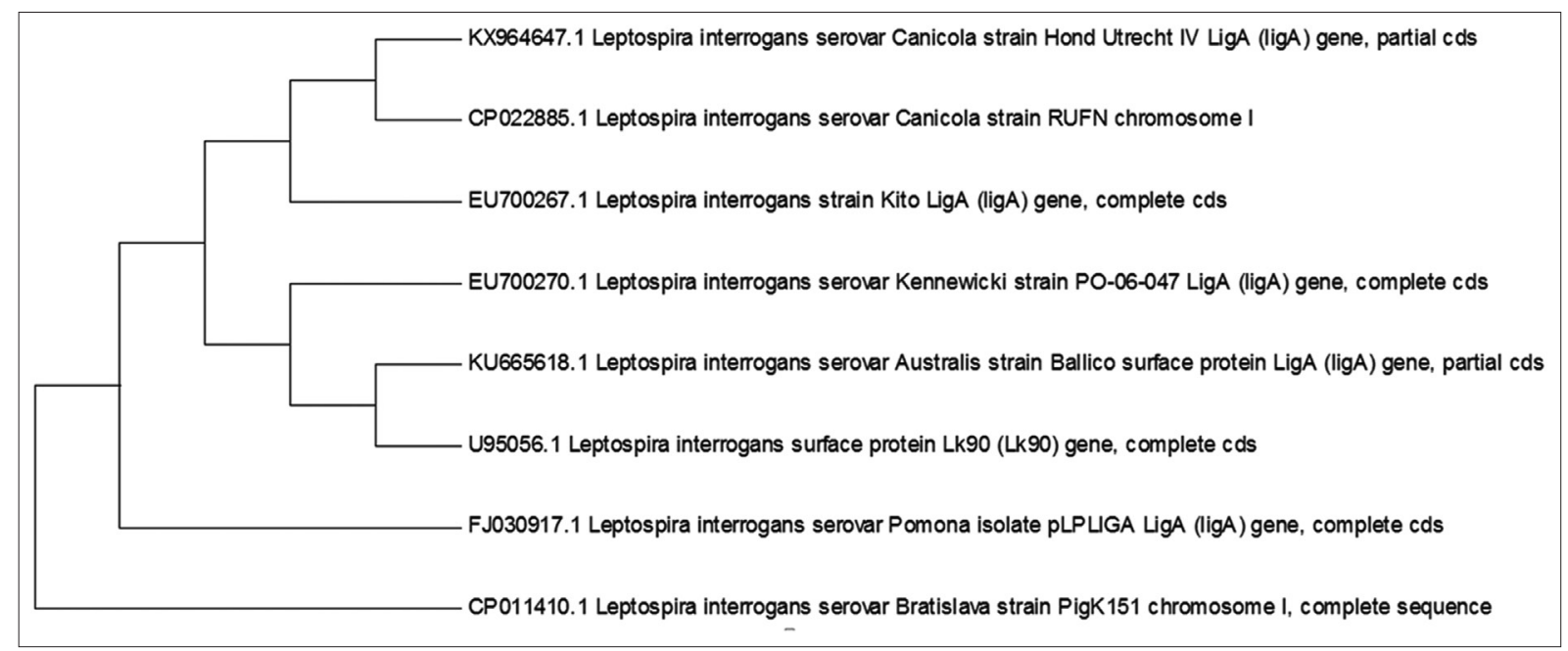

Figure-3: Leptospira interrogans serovar Canicola strain Hond Utrecht IV LigA (ligA) gene, partial CDS sequence phylogenetic tree. 
effect of recombinant $\operatorname{Lig} A N 1$ protein, a truncated form of LigA comprising a carboxy-terminal repeat domain unique to the LigA [11-13]. In this study, we have amplified a $1491 \mathrm{bp}$ fraction of the ligA gene, within the LigAN1 region, encoding hydrophilic amino acids from 624 to 1121 . The amplified DNA sequence was cloned on to $\mathrm{pET}$-32a expression vector using host E.coli $\mathrm{DH} 5 \alpha$. The $\mathrm{pET}$ vectors are considered to be one of the most powerful vector systems developed for cloning and expression of bacterial genes in E. coli [14]. The pET-32a (+) vector series is designed for expression of peptide sequences fused with the 6X histidine tags. Target genes cloned in pET plasmids are placed under the control of a strong bacteriophage T7 promoter and expression is induced by providing a source of T7 RNA polymerase in the host cell. The T7 RNA polymerase is highly selective and active and helps in targeting almost all of the cells' resources on the expression of the specific gene. In a study, the parasporin 1 gene of Bacillus thuringiensis was amplified by PCR and cloned into pGEM-vector. The predicted protein encoded by the 2371 nucleotides' long gene sequence was composed of 789 amino acids with an estimated molecular weight of $84 \mathrm{kDa}$ [15]. Vector pRham-SUMO was used to clone and sequence the nagH gene of $C$. chauvoei [16]. In another study, P67 gene of Mycoplasma leachii was cloned in pRham N-His SUMO Kan vector and transformed into competent Escherichia cloni $10 \mathrm{G}$ cells [17]. In this study, the pET-32a ligA construct was transformed into E. coli DH5 $\alpha$, an expression host that lacks T7 RNA polymerase gene. E. coli is the most preferred host in recombinant DNA technology because its genome is well studied, is relatively cheap and has short generation time [18]. The phylogenetic tree revealed that the $\operatorname{lig} A$ gene of the tested strain of Leptospira species occupied the same position in the phylogenetic tree as other reference leptospiral strains of the particular species. This confirmed that the ligA gene was conserved in the genus Leptospira and hence indicated that the LigA protein was a probable candidate for subunit vaccines. The truncated recombinant LigA protein for vaccine studies may be expressed by subcloning the pET-32a lig $A$ construct into $E$. coli BL21 (DE3) expression system and induction with isopropyl $\beta$-D-1-thiogalactopyranoside (IPTG) [19].

\section{Conclusion}

The results of the study reveal that the partial $\operatorname{lig} A$ gene can be cloned into pET-32a- E. coli DH5 $\alpha$ system. The phylogenetic analysis revealed that the partial $\operatorname{lig} A$ gene was conserved in the genus Leptospira. Hence, further studies need to be conducted on the immunogenicity and vaccine properties of the protein.

\section{Authors' Contributions}

MS carried out the study. MS prepared the article. MM and SJ formulated the study. JT, TGS, NC, RA,
BKM, and RB participated in scientific discussions. All authors read and approved the final manuscript.

\section{Acknowledgments}

The authors are highly thankful to the Dean, College of Veterinary and Animal Sciences, Mannuthy, for providing facilities andfund for this study.

\section{Competing Interests}

The authors declare that they have no competing interests.

\section{References}

1. Evangelista, K.V. and Coburn, J. (2010) Leptospira as an emerging pathogen: A review of its biology, pathogenesis and host immune responses. Future Microbiol., 5: 1413-1425.

2. Levett, P.N. (2008) International committee on systematics of prokaryotes. Subcommittee on the taxonomy of leptospiraceae. Int. J. Syst. Evol. Microbiol., 58: 1049-1050.

3. Lehmann, J.S., Matthias, M.A., Vinetz, J.M. and Fouts, D.E. (2014) Leptospiral pathogenomics. Pathogens, 3: 280-308.

4. Thibeaux, R., Iraola, G., Ferres, I., Bierque, E., Girault, D., Gilbert, M.E.S., Picardeau, M. and Goarant, C. (2018) Deciphering the unexplored Leptospira diversity from soils uncovers genomic evolution to virulence, Microb. Genom., 4(1).

5. Srivastava, S.K. (2006) Prospects of developing Leptospiral vaccines for animals. Indian J. Med. Microbiol., 24: 331-336.

6. Sambrook, J. and Russell, J.W. (2001) Molecular Cloning-A Laboratory Manual. $3^{\text {rd }}$ ed. Cold Spring Harbor Laboratory Press, Cold Spring Harbor, New York.

7. Sanger, F., Nicklen, S. and Coulson, A.R. (1977) DNA sequencing with chain-terminating inhibitors (DNA polymerase/nucleotide sequences/bacteriophage 4X174). Proc. Natl. Acad. Sci. U. S. A., 74: 5463-5467.

8. Tamura, K., Stecher, G., Peterson, D., Filipski, A. and Kumar, S. (2013) MEGA6: Molecular evolutionary genetics analysis version 6.0. Mol. Bio. Evol., 30: 2725-2729.

9. McBride, A.J.A., Cerqueira, G.M., Suchard, M.A., Moreira, A.N., Zuerner, R.L., Reis, M.G., Haake, D.A., Ko, A.I. and Dellagostin, O.A. (2009) Genetic diversity of the Leptospiral immunoglobulin-like (Lig) genes in pathogenic Leptospira spp., Infect. Genet. Evol., 9: 196-205.

10. Palaniappan, R.U.M., Chang, Y.F., Jusuf, S.S.D., Artiushin, S., Timoney, J.F., Mcdonough, S.P., Barr, S.C., Divers, T.J., Simpson, K.W., Mcdonough, P.L. and Mohammed, H.O. (2002) Cloning and molecular characterization of an immunogenic LigA protein of Leptospira interrogans, Infect. Immun, 70: 5924-5930.

11. Palaniappan, R.U.M., McDonough, S.P., Divers, T.J., Chen, C.S., Pan, M.J., Matsumoto, M. and Chang, Y.F. (2006) Immunoprotection of recombinant Leptospiral immunoglobulin-like protein against Leptospira interrogans serovar Pomona infection. Infect. Immun., 74: 1745-1750.

12. Silva, E.F., Medeirosc, M.A., McBride, A.J.A., Matsunaga, J., Esteves, G.S., Ramos, J.G.R., Santos, C.S., Croda, J., Homma, A., Dellagostin, O.A., Haake, D.A., Reis, M.G. and Ko, A.I. (2007). The terminal portion of Leptospiral immunoglobulin-like protein LigA confers protective immunity against lethal infection in the hamster model of leptospirosis. Vaccine, 14: 6277-6286.

13. Hartwig, D.D., Oliveira, T.L., Seixas, F.K., Forster, K.M., Rizzi, C., Hartleben, C.P., McBride, A.J.A. and Dellagostin, O.A. (2010) High yield expression of leptospirosis vaccine candidates LigA and LipL32 in the methylotrophic yeast Pichia pastoris. Microb. Cell. Fact., 9: 98.

14. Sadeghi, M.M., Rabbani, M., Rismani, E., Moazen, F., 
Khodabakhsh, F., Dormiani, K. and Khazaei, Y. (2011) Optimization of the expression of reteplase in Escherichia coli. Res. Pharm. Sci., 6: 87-92.

15. Assaeedi, A.S. and Osman, G.H. (2017) Isolation, cloning, DNA sequencing and bioinformatics analysis of the parasporin-1 gene of Bacillus thuringiensi. J. Proteomics Bioinformatics, 10: 144-151.

16. Dangi, S.K., Yadav, P.K., Tiwari, A. and Nagaleekar, V.K. (2017) Cloning and sequence analysis of hyaluronoglucosaminidase (nagH) gene of Clostridium chauvoei. Vet World, 10: 1104-1107.

17. Thankappan, S., Rana, R., Remesh, A.T., Rekha, V.,
Nagaleekar, V.K. and Puvvala, B. (2017) Cloning and expression of P67 protein of Mycoplasma leachii. Vet World, 10: 1108-1113.

18. Fakruddin, M.D., Mazumdar, R.M., Mannan, K.S.B., Chowdhury, A. and Hossain, M.N. (2013). Critical factors affecting the success of cloning, expression, and mass production of enzymes by recombinant E. coli. ISRN Biotech., 2013: 590587.

19. Mierendorf, R.C., Morris, B.B., Hammer, B. and Novy, R.E. (1998) Expression and purification of recombinant proteins using the pET system. Methods Mol. Med., 13: 257-292.

$* * * * * * * *$ 